\title{
A DISCOURSE STUDY OF SELECTED NEWSPAPER HEADLINES ON INSURGENCY IN NIGERIA
}

\author{
Eyang Anthony Ebebe ${ }^{1 *}$, Ghevolor Asa John² and Matthew Abua Ebim ${ }^{3}$ \\ ${ }^{1}$ Department of English \& Literary Studies, University of Calabar, PMB 1115 Calabar, Cross \\ River State Nigeria \\ ${ }^{2}$ Department of English \& Literary Studies, University of Calabar, PMB 1115 Calabar, Cross \\ River State Nigeria \\ ${ }^{3}$ Department of English \& Literary Studies, University of Calabar, PMB 1115 Calabar, Cross \\ River State Nigeria
}

*Corresponding Author Email: meabua@yahoo.com; Tel: +23408038881284; orcid.org/0000-0003-4902-5009

Cite this article:

Eyang A.E., Ghevolor A.J., Matthew A.E. (2021), A Discourse Study of Selected Newspaper Headlines on Insurgency in Nigeria. International Journal of Literature, Language and Linguistics 4(1), 64-88. DOI: 10.52589/IJLLL-16W9NQ29.

\section{Manuscript History}

Received: 17 Aug 2021

Accepted: 13 Sept 2021

Published: 22 Sept 2021

Copyright $\odot 2020$ The Author(s). This is an Open Access article distributed under the terms of Creative Commons AttributionNonCommercial-NoDerivatives 4.0 International (CC BY-NC-ND 4.0), which permits anyone to share, use, reproduce and redistribute in any medium, provided the original author and source are credited.
ABSTRACT: Insurgent activities are so prevalent in Nigeria that the security apparatus finds it very difficult if no almost impossible to curb their excesses. On a daily basis, newspapers are flooded with the wanton destruction of the activities of these elements in the Nigerian society. The headlines of those media reports are therefore selected for analysis in this study. In this study, we draw samples of data, present and group them into number texts and then give a detailed analysis through the application of linguistic tools. We focus the analysis on identifying the linguistic and discourse patterns in the data by using conceptualization and representation as Critical Discourse Analytical and Metaphorical concepts to critically examine the issues in relation to insurgency. Ideological projections are also taken into consideration from both the media practitioners' perspectives and the militants' points of view. For easy identification, the data were arranged in terms of their thematic realization and grouped into two broad categories: according to the issues raised and according to the surface as well as underlying meaning realizable in the message. The analysis was presented in relation to the Boko Haram and Niger Delta insurgency in Nigeria. In spite of their differences in terms of ideology and modus operandi, the analysis was done add to the body of literature on the issue.

KEYWORDS: Newspaper Headlines, Insurgency, Nigeria 


\section{INTRODUCTION}

Insurgent activities are so prevalent in Nigeria that the security apparatus finds it difficult if not almost impossible to curb the excesses of the perpetrators. On a daily basis, newspapers are flooded with the wanton destruction of the activities of these elements in Nigeria. The headlines and news contents of those media reports are elicited for analysis in this study where we draw samples of data, present and group them into number texts and then give a detailed analysis through the application of linguistic tools. The analysis focuses on identifying the linguistic and discourse patterns in the data by using conceptualization and representation as Critical Discourse Analytical and to examine the issues in relation to insurgency. Ideological projections are also taken into consideration from both the media practitioners' perspectives and the militants' points of view. For easy identification, the data were arranged in terms of their thematic realization and grouped into two broad categories: according to the issues raised and according to the surface as well as underlying meaning realizable in the message. The analysis focuses on Boko Haram and Niger Delta Militants. In spite of their differences in terms of ideology and method of operations, we discover that both characters indulge in: polarization, ideological depictions, radicalizations and the portrayal of the government as enemies by engaging in destructive activities

\section{Lexical Representation of Insurgency and the Major Actors}

Lexical representation of insurgency in this study is significant because naming and lexical choices are value-laden and ideologically charged. A lot of work has dealt extensively on this subject matter, for instance, Matthew Abua Ebim's works explored the "pattern of propaganda rhetoric in the media to enact and represent the prevalent realities of the Boko Haram ideologies in Nigeria by examining and analysing the responses, reactions and the utterances by the major actors in the raging insurgency wars" They also scrutinized "the issue of linguistic labeling in the media in relation to militants activities and opined that there is the need to evaluate the various labels associated with militants as seen in the media so as to determine their ideological disposition." (See Matthew Abua Ebim (2021a, 2021b, 2021c, 2021d, 2019a, 2019b, Kress, 1983; van Dijk 1995; Clark 1998; Ghevolor 2013 and Ghevolor \& Essien-Eyo 2018). The most classic example of lexicalization is that the naming choice is based on the ideology of those who name (Thetela, 2001: 354). Allan (1999: 178-9). Based on this, Fairclough argues that "a text's choice of wording depends on, and helps create, social relationships between participants" (1999: 116) and in the words of Huckin (1995: 101), "special attention should be given to studying words and phrases because "labels often carry unavoidable connotations". He uses the word "abortion" as an example; and those who support it he referred to them as "prolife" while those who opposed it he labelled "anti-choice". While working on feminist ideology in literary texts, Ghevolor (2013) and Ghevolor \& Essien-Eyo (2018) observed that "deviant feminist discourse engenders ideological miscommunication amongst women due to a multiplex of sociological factors such as ethnicity, education, socio-economic status, environment and the socio-cultural norms of a given society influence women's ideology" and further observed that "each woman has her individual talk-style which translates to her individual feminist ideology and which has either a positive or a negative impact on feminist ideological and socio-cultural stability amongst women groups and that such talk-styles that maintain socio-cultural feminist ideology are considered as having positive impacts on sociocultural stability." 
The approach adopted in this study is concerned with lexical items that carry or can be interpreted to carry positive or negative assessments of people, places, happenings, things, states of affairs, etc. Such instances include items that trigger a positive or negative assessment of people, places, things, happenings and states of affairs in the reader's cognition (or the listener's, in case of verbal utterances). Our analysis of lexicalization draws mainly from the Judgment subsystem as it is concerned with the textual realizations that most likely occur in news reporting as Martin observes "Judgment is the institutionalization of feeling, in the context of proposals (norms about how people should and shouldn't behave" (2000:155). Thus, we have two types of Judgment: positive Judgment and negative Judgment.

In the process of explicating the ideological projections of the Boko Haram and Niger Delta we take a look at the issues from diverse ways as Ebim (2017:141) opines "The social actors and their behaviour thus may be judged as acceptable or unacceptable, moral or immoral, legal or illegal". However, Jovanovic-Krstic stresses that "Judgment is highly determined by cultural and ideological values, and as such what is viewed as appropriate in one culture may not be viewed in the same light in another" (2000: 75). The study, therefore, draws on what is acceptable or acceptable in the Nigerian context while taking extracts from the data as case studies. In the analysis of the lexical items in the data, we consider the way participants are referred to and their responses (Reisigl and Wodak, 2001; van Dijk, 1993).

\section{DATA PRESENTATION}

Insurgencies in Nigeria are as varied as the various articles published on the phenomenon and for that purpose, data for analysis in this study were divided into eight (8) sections with the topical issues treated under such issues. Such data categorization is presented below. The data were segmented into ExtractsA1 to Extracts G 108 with numbers denoting the actual amount of data for a particular topic. For example EXTRACT A which focuses on Amnesty/Resource Control ranges from A1-A18, EXTRACT B which focuses on Militancy/Vandalism/Bunkering ranges from B19-B30, EXTRACT C with its focus on Environmental Despoliation/ Economy ranges from C31-C40, EXTRACT D which focuses on Ethnic Violence/Clashes/Armed Struggle ranges from D41-D65, EXTRACT E which focuses on Politics/Religious extremism and terrorism ranges from E61-E79, EXTRACT F with its focus on kidnapping, speculation and blame game ranges from F80-F98, EXTRACT G with the focus on Education and terrorism ranges from G91-G108.

\section{Below is a presentation of the data:}

\begin{tabular}{|l|l|l|}
\hline S/N. & TOPICS & EXTRACTS \\
\hline I. & Amnesty/Resource Control & EXTRACT A \\
\hline II. & Militancy/Vandalism/Bunkering & EXTRACT B \\
\hline III. & Environmental Despoliation/ Economy & EXTRACT C \\
\hline IV. & Ethnic Violence/Clashes/Armed Struggle & EXTRACT D \\
\hline V. & Politics/Religion Extremism \& Terrorism & EXTRACT E \\
\hline VI & Cultists, Kidnappers \& Negotiators & EXTRACT F \\
\hline VII. & Educational Terrorists & EXTRACT G \\
\hline
\end{tabular}


TABLE 1 Showing types of data, No of Occurrences and Percentage Distribution.

\begin{tabular}{|l|l|l|}
\hline Types of Data & No of Occurrences & \%Distribution \\
\hline Amnesty/Resource Control & 18 & $16.66 \%$ \\
\hline Militancy/Vandalism/Bunkering & 11 & $10.18 \%$ \\
\hline Environmental Despoliation/ Economy & 9 & $8.33 \%$ \\
\hline Ethnic Violence/Clashes/Armed Struggle & 19 & $17.59 \%$ \\
\hline Politics/Religious extremism \& Terrorism & 18 & $16.66 \%$ \\
\hline Cultists, Kidnappers Speculation & 18 & $16.66 \%$ \\
\hline Educational Terrorists & 9 & $8.33 \%$ \\
\hline GRAND TOTAL & $\mathbf{1 0 8}$ & $\mathbf{1 0 0 \%}$ \\
\hline
\end{tabular}

From the above table, we observe that ethnic violence, clashes and armed struggle top the list with a total of 19 extracts and a percentage distribution of $17.59 \%$. Closely followed are politics, religious extremism \& terrorism with a total of 18 extracts and a percentage distribution of, $16.66 \%$ and the Kidnapping, Speculations \& Blame games with a total extract of 18 texts and percentage distribution of $16.66 \%$. The issues of Amnesty and Resource Control came close with a total of 18 extracts and a percentage distribution of $16.66 \%$ closely followed in that order is the issue of militancy, vandalism \& oil bunkering with a total occurrence of 11 extracts and a percentage distribution of 10.18\%. Environmental despoliation has a total of 9 extracts and a percentage distribution of $8.33 \%$. And lastly, education and terrorism have a total of 9 extracts and a percentage distribution of $8.33 \%$.

\section{DATA ANALYSIS}

\section{HEADLINES}

Headlines as van Dijk (1988:191) observed are particularly important because, both in production and in the reception of news reports, they subjectively define the most prominent or most relevant information of the news item. This means headline express-sometimes in a biased way-the top of the underlying semantic macrostructure, and at the same time define the situation reposed in the press. Since headlines are often the only information read or memorized, they play an important role in further information processing and the possible effects of news. Headlines, therefore, correspond more or less with the themes they summarize.

Commenting on the use of headlines, Taiwo (2007:43) averred that Newspaper headlines act as forerunners to news reports by revealing the social, cultural and national representations circulating in the society at any given time. This means that newspaper headlines reach an audience considerably wider than those who read the news story. This is observable in the situation whereby vendors display their newspapers, several people including passers-by and casual readers take a glimpse at the headlines which may later become the subject of discussion in their offices, at home or any other domain. This is because front-line headlines are more carefully chosen to evoke some emotions in the readers. This unique position of the headline prompts Taiwo (2004:324) to assert that newspaper editors deliberately go for eye-catching expressions because headlines are strategically used by the editor who chooses emotive vocabulary and rhetorical graphological devices to make an impact on the readership. From the 
foregoing, we observe that headlines are unique types of texts that encapsulate the story in a minimum number of words and that often display some significant linguistic and graphological features (see Reah 1998:13, Chiluwa 2012: 43). Based on our observation so far, the following samples of headlines labelled A1-A10 from our data demonstrate how real messages and ideological beliefs are embedded in newspaper headlines in relation to the insurgency in Nigeria.

\section{A1. Amnesty to Ghosts}

A2. Police HQ Bomb Blast: Jonathan queries IGP Ringim

A3. Boko Haram financier arrested in Maiduguri

A4. JTF Uncovers Oil Spill from Shell Pipeline

A5. 156TRN Needed to Clean Up Niger Delta

A6. 50 Yobe College Students Shot Dead

A7. 186 More Ex-Militants for foreign training

A8. Boko Haram's Shekau Likely Dead JTF Says

A9. Boko Haram resurrects, declares total Jihad

A10. Bishop Backs Capital Punishment

Even though the focus of this study is not on the analysis of headlines, it is necessary to describe and interpret the relevance of headlines in news reports since they act as precursors to the main news item. There is hardly any news item without a headline because headlines act as the doorway to the main story. For example, the headline A1 on AMNESTY TO GHOSTS depicts the Boko Haram insurgents as faceless individuals who should not be granted amnesty by the federal government. Some believe that for the Boko Haram militants to be granted amnesty, they should come out of hiding and dialogue with the federal government while the insurgents are of the view that when they come out of hiding, they will be arrested and prosecuted, hence the need for them to remain in hiding. The newspaper headline, therefore, refers to the Boko Haram insurgents in that story as "ghosts", a metaphor for faceless individuals. The headline A2 is on the bombing of the police headquarters in Abuja and it reads: Police HQ Bomb Blast: Jonathan Queries IGP Ringim. For anybody to understand the linguistic import of this headline, the person must be conversant with the story. The then-president was said to have issued a query to the then Inspector General of Police mister Ringim to explain how such an attack was carried out without the police hierarchy knowing about it or getting a security report on it. The next two headlines A3 \& A4 focus on Ethnic Violence, Clashes \& Armed struggles. They have the same thematic preoccupation i.e. Boko Haram insurgency. While the first extract tries to explain how BH financier who was a serving commissioner in Borno state Northeastern Nigeria was arrested the second extract apportions blame on the shell for oil spillage in the Niger Delta, and A5 states the amount of money needed to clean the land: an amount estimated at about 156 trillion naira. In the headlines on education, there is a bit of irony in them. While A6 is on the mayhem unleashed on school children in the northern part of the country, A7 focuses on the training given to the Niger Delta ex-militants. A total number of 50 college students were shot dead as reported in that headline: 50 Yobe College Students Shot Dead, while a total number of 186 ex-militants were sent abroad on training as reported in that headline: 186 more Ex- 
Militants For Foreign Training reads A8 thus juxtaposing the positive and the negative which could possibly cause an outrage. Headline A8 \& A9 on Boko Haram's Shekau Likely Dead and Boko Haram resurrects, declares total Jihad are merely speculative. Headline A8 was at some point in the Nigerian media reportage, a recurrent decimal where there were speculations on whether the Boko Haram leader Abubakar Shekau was killed by the security agents or not. But in this particular one, the security department said the insurgent leader was dead but got itself confused by using the lexical item "likely" which tends to portray the story as merely speculative. Headline A9 on the same "dead" Shekau did not only "resurrect" but "declared total jihad"- a religious war that is aimed at Islamising the entire nation. This is speculative because Nigeria is not a mono-religious society so the tendency to declare a "total jihad" can only be realistic on the headlines and pages of newspapers. Headline A10 portrays a Christian bishop as saying he "throws his weight behind capital punishment for offenders who are found guilty of murder trying to make him look like the proponent of the law whereas the extant laws are already there to handle such issues.

\section{Lexical Choices in The Data}

At the level of lexical analysis, debates on insurgency need to express underlying concepts and beliefs in specific lexical items. Similar meanings may thus be variably expressed in different words, depending on the position, role, goals, point of view or opinion of the reporter, speaker, that is, as a function of context features. Such instances of linguistic labels are predominant in the data below:

The Nigeria Police have arrested 10 oil pipeline vandals and recovered 800 units of 50 litres jerry cans filled with stolen oil in Ogun state. DATA A1

Navy hands over six suspected oil thieves to EFCC for further investigation and possible prosecution. DATA A2

Nigeria is losing over $35 \%$ of its power generation capacity to the activities of vandals, the Minister of Power, Prof. Chinedu Nebo has said. The Minister made this revelation while speaking at the opening ceremony of a two-day Stakeholders Forum on the protection of critical national assets and infrastructure at the International Conference Centre, Abuja DATA A3.

Oil thieves face 21 years in jail. DATA A4

Niger Delta ex-militants, also known as ex-agitators under the Phase Three Amnesty, have threatened to halt oil production in the region. DATA A5

"Six pirates were killed in the encounter while one escaped into the river with gunshot wounds". Few days, however, human rights activists and families of the purported suspects raised dust over the killings, alleging extra-judicial murder. They claimed there was no exchange of gunfire between the youths (suspects) and soldiers who arrested them before they were murdered.

DATA A6. 
"On 21st August 2011 about 1300 hours joint operations by all security services led to the arrest of two (2) notorious leaders of the Boko Haram extremist sect, namely, Babagana Ismail KWALJIMA (a.k.a Abu SUMMAYA) [and] Babagana MALI (a.k.a Bulama)". "Meanwhile the suspects have made valuable statements and are being held at a military facility," ... investigation had revealed that one Mamman Nur, "a notorious Boko Haram element with Al-Qaeda links who returned recently from Somalia, working in concert with the two (2) suspects masterminded the attack on the United Nations (UN) building in Abuja". DATA A7.

The use of such words as: "vandals" "pipeline thieves" "stakeholders" "ex-militants" "exagitators" "pirates" "notorious leaders" "notorious Boko Haram elements" "KWALJIMA" "Abu SUMMAYA" "MALI (a.k.a Bulama)" "Mamman Nur" are elements of lexicalization that tend to give the notion of the "other" and "us".

\section{AMNESTY AND RESOURCE CONTROL}

In May 2007, the then President, Umaru Yar'Adua inaugurated the Amnesty committee with a promise to address the Niger Delta conflict, and so included the issue in his seven-point agenda. Working in tandem with the elders from the region to fulfil his promise, the then President inaugurated the Technical Committee on the Niger Delta, (Obi \& Rustad, 2011). The 45member Committee was inaugurated on 8th September 2008 to collate and review all past reports on Niger Delta, appraise their recommendations and make other proposals that could assist the Federal Government to achieve sustainable development, peace, human and environmental security in the region. The Committee under the Chairmanship of Ledum Mitee, MOSOP President had submitted its report (Report of the Technical Committee on the Niger Delta, 2008) to the Federal Government on the 1st of December 2008 (Mitee, 2009). Part of recommendations included: Appointing a mediator to facilitate discussions between government and militants; granting of amnesty to some militant leaders; launching disarmament, demobilization and rehabilitation campaign, and increase in the percentage of oil revenue to the Niger Delta to 25 per cent from the initial 13 per cent; establishing regulations that could compel oil companies to have insurance bonds; making the enforcement of critical environmental laws a national priority; exposing fraudulent environmental clean-ups of oil spills and prosecuting operators, ending gas flaring by 31st December 2008 as previously ordered by the Federal Government (Report of the Technical Committee on the Niger Delta, 2008). Following the federal government's determination to address the Niger Delta issues, the government partly yielded to the report of the Technical Committee by setting up a Presidential Panel on Amnesty and Disarmament of Militants in the Niger Delta on the 5th of May, 2009 to implement the recommendation concerning the granting of amnesty to Niger Delta militants (Olubayo \& Olubisi, 2012:7).

In its recommendations, the Panel set out the terms, procedures and processes of the grant of an amnesty to the Niger Delta militants. Accepting the recommendations, President Umaru Yar'Adua pursuant to section 175 of the 1999 Constitution of Nigeria granted 'amnesty and unconditional pardon to all persons who have directly or indirectly participated in the commission of offences associated with militant activities in the Niger Delta' (Vanguard, 2009). Under Section 175, the President may, after consultation with the Council of State (a) 
grant any person concerned with or convicted of any offence created by an Act of the National Assembly a pardon, either free or subject to lawful conditions; (b) grant to any person a respite, either for an indefinite or for a specified period, of the execution of any punishment imposed on that person for such an offence; (c) substitute a less severe form of punishment for any punishment imposed on that person for such an offence; or (d) remit the whole, or any part of any punishment imposed on that person for such an offence, or of any penalty, or forfeiture otherwise due to the State on account of such an offence. The amnesty which was unveiled on 25th June 2009 was scheduled to run between 6th August to 4th October 2009, that is, a 60day period; and was 'predicated on the willingness and readiness of the militants to give up all illegal arms in their possession, completely renounce militancy in all its ramifications unconditionally, and depose to an undertaking to this effect (Federal Government of Nigeria, Niger Delta Amnesty Programme). The amnesty programme in the Niger Delta came with the process of Disarmament, Demobilization and Reintegration (DDR) which is said to be one of the most important ways of resolving conflicts and managing the post-conflict situations in the world to ensure peace. The amnesty itself involves three phases: the disarmament and demobilisation of militants; the rehabilitation and integration of ex-militants and the final stage is the post-amnesty package of huge infrastructural development. The disarmed militants were to be taken to designated collection points and camps in six Niger Delta states, with a promise of a payment of N65, 000 [approximately \$407 USD] monthly, the payment of rent and offering of vocational training (Oluwaniyi, 2011). During the first phase of the programme, several militants turned in several arms and ammunition (Kuku, 2011). Indeed, it was recorded that about 26,358 ex-militants accepted the amnesty offer (first phase- 20,192 militants representing those that accepted the offer on or before 4 October 2009, while the second phase of the amnesty programme that occurred in November 2010 comprises 6,166 militants representing those that accepted the offer post 4 October 2009). This appeared to have reduced the incidence of conflict and the accumulation and influx of arms by militants in the region. Some rehabilitation centres were provided for the second stage which was tailored to meet the training needs of the ex-militants. The trainings were to be done in batches as the centres could only accommodate few numbers of registered ex-militants. It was expected that each batch would spend four weeks in the rehabilitation programme, which involves reorientation, counselling and moral/spiritual regeneration of the ex-militants (Akinwale, 2010).

\section{THE NIGER DELTA CASE STUDIES}

Our focus on the data tagged: Amnesty/Resource Control is to explicate the media's use of language to represent insurgent activities and the major actors. In extract A1 below, one of the frontline militant leaders in the Niger Delta region Tompolo regretted his decision to even embrace the amnesty:

Accepting amnesty is my most difficult decision -Tompolo: The challenges we are facing are much, I know that in a contract like this, you will definitely face challenges, but I am prepared for them and know that after some time, we will overcome them. For people to develop the Niger Delta, it will take some time, and that is the more reason we are even appealing to our governors because there are things the states are supposed to handle. Like you don't expect somebody from the presidency or Abuja to come and do roads in Warri. They have their own functions and the states have theirs too. DATA B1. 
The headline is clear and straight to the point; expressing the difficulties involved in deciding to change or switch from a particular lifestyle to another while not being aware of the challenges ahead. Mr Tompolo makes it clear that the leaders of the region were not doing enough to ensure that the development of the region is sustained and commensurate with the resources that are found therein. Such inadequacies on the part of the leaders are embedded in the word "challenges". He, however, did not demystify the ambiguity in such a word because a challenge could be either that the infrastructural development in the region is non-existent, slow or that the ex-militants were not adequately funded to continue in the luxurious lifestyles they were used to. While "appealing" to the leaders in the Niger Delta region to expedite actions towards development, he also accused them of over-relying on the "centre" which it calls "presidency" or "Abuja". The terms "Presidency" and "Abuja" as used above are metaphors for the seat of power in Nigeria which is the power of the president of the federal republic and the meeting point for decision making in the country. He questions the decision to entrust the responsibility of developing the region to the presidency while the governors were adequately funded. There is however a deviation from placing the entire blame on the governors to incorporating the federal government this time on appeal.

We are appealing to all of them to try on their own to do what they are supposed to do. Even President Goodluck Jonathan cannot develop the whole of the Niger-Delta if he happens to rule for eight years because for you to construct a bridge from here (Warri) to Forcados, it may take up to six or eight years, so if you want to do it before you will put the paper works together, it will take another one to two years. It is a gradual process that is why we are still mounting pressure on the Federal Government to see that they start something now. DATA B2.

The use of the word "them" above points to all the governors of Niger Delta extraction including the six states of Cross River, Delta, Edo, Rivers, Akwa Ibom and Bayelsa. The implication is that the development of the region is an approach that should be embraced by all stakeholders if the amnesty was to be effective. The militant leader beams his lenses on the future and concludes that even the eight-year tenure of a sitting president cannot make any meaningful impact on the development of the region. According to him: Even President Goodluck Jonathan cannot develop the whole of the Niger-Delta if he happens to rule for eight years because for you to construct a bridge from here (Warri) to Forcados, it may take up to six or eight years, so if you want to do it before you will put the paper works together, it will take another one to two years. This paints a clear picture of the nature of the region's soil which had been besmirched as a result of the oil exploration over the years. And the emphasis on particular areas shows that the militant leader is conversant with the environment.

FG urged to carry along ex-militants: The Federal Government has been urged to absorb all repentant militants and their boys for the amnesty programme to be a success in the Niger Delta region. A former Commander of Movement for the Emancipation of Niger Delta, MEND, Sobomo Jack, who spoke to Vanguard, yesterday, said he was worried by some of the developments in the ongoing amnesty programme. He urged the Federal Government to ensure that all former militant leaders and repentant militants, who have demonstrated genuine 
repentance, are absorbed in the amnesty programme, adding that a situation where the amnesty committee seems to be neglecting some groups in the region was not healthy for the exercise.

\section{DATA B3}

The headline above epitomizes a journey metaphor because "carry-along" entails a movement that could be vehicular but within this context, the term "carry-along" entails being incorporated into the amnesty programme to ensure peace in the Niger Delta region. The persona in the above extract is aggrieved that certain areas in the implementation process were not right but the use of certain lexical items calls to mind the issue of "leadership" and "following" within the hierarchy of the militant groups. He, however, used the word "their boys" to refer to the foot soldiers within the militancy fold. Such insinuations are captured in the following texts from the above extract: "all repentant militants and their boys" "he was worried by some of the developments in the on-going amnesty programme" "all former militant leaders and repentant militants, who have demonstrated genuine repentance" "a situation where the amnesty committee seems to be neglecting some groups in the region was not healthy for the exercise." "To repent" is to turn a new leaf and embrace a change within the Christendom to ensure that one seeks the face of God. For militants to say they have repented means that they acknowledge the fact that they were doing something bad or contrary to the laws of the land. While the plea for incorporating the "repentant" militants is spearheaded, there are dissenting views from other quarters:

Group urges FG not to extend the deadline for unrepentant militants: Concerned Niger Delta Group (CNDG) has cautioned the Federal Government against extending the October 4, 2009, deadline given militants in the region to disarm, and's warning that the government should not treat the un-repentant militants with kid-glove any longer. DATA B4

The CNDG in a statement signed by its president, Comrade Tare Oweikeyi and two others said it was regrettable that the government has started pandering to the capricious whims of the militants once again. It noted: "It was this kids glove treatment in handling these boys that snowballed into full-blown belligerency and armed confrontations with trained military men to the chagrin of all right-thinking persons in the region" DATA B5

Extracts A4\&A5 serve as a caution to the federal government on the need to ensure strict adherence to the rules that govern the amnesty programme so as not to give undue advantage to certain elements. The extracts also state the repercussions of being "lenient" with the process. The use of the expression: government should not treat the un-repentant militants with kid's glove encourages a violent approach to the disarmament process an act that could lead to the escalation of the insurgent activities in the region as well as jeopardises the entire amnesty programme. By saying "It was this kid-glove treatment in handling these boys that snowballed into full-blown belligerency and armed confrontations with trained military men to the chagrin of all right-thinking persons in the region" is ironic because the amnesty programme does not 
involve the use of iron fist but a "carrot and stick" approach which looks good at the initial stage and is seen to be sustained to avoid a reversal to the status quo ante. Extract A4, however, is a deviation from the principles of leniency and persuasion which are expected to encourage a peaceful resolution of the insurgency and not a resort to violence.

Amnesty: Niger Delta Militants Besiege National Assembly: Hundreds of ex-militants from the Niger Delta region Thursday stormed the National Assembly to protest their alleged exclusion from the amnesty programme. The protesters, who came under the aegis of the Niger Delta Freedom Fighters (NDFF), barricaded the main gate of the parliament, chanting war songs and demanding to meet the leadership of the National Assembly.

\section{DATA B6}

The ex-militants led by one Mr Para Ekiyes said they were at the parliament to seek the intervention of the lawmakers on their alleged exclusion from the third phase of the programme which they claimed had commenced in some states of the Niger Delta. The aggrieved ex-militants threatened to return to the creeks to resume hostilities against oil multinationals if the federal government failed to enlist them in the various programmes being run by the Amnesty Office. DATA B7

The headline on extract A6 sounds threatening by using the word "besieged" "beleaguered" "fraught" "apprehensive" etc. to "besiege" is to "lay ambush" or wait for an individual to unleash terror and in that headline, the ex-militants were said to have arrived in the nation's capital to unleash terror by "besieging" the national assembly. This is further corroborated with the use of the word "stormed" which sounds like a threat to the peace and stability in governance. This also points to the fact that all was not well at that moment. The reporter's personal emotions were brought into the reportage through the use of the word "alleged" which connotes an unsubstantiated point in the struggle for incorporation into the amnesty programme by the ex-militants. To "allege" to have been excluded from the amnesty entails lying on the part of the ex-militants. If they were lying, the government documents would have proved them wrong. As revealed in extract A7 the militants were said to have gone to seek the "intervention" of the government through the national assembly and not to harass the seat of power. These expressions tend to prove the point on the need for a peaceful resolution of the insurgent activities: "the intervention of the lawmakers on their alleged exclusion" "which they claimed had commenced" "militants threatened to return to the creeks to resume hostilities against oil multinationals". Were those who "stormed" the national assembly "excluded" from the programme? If not why would they "storm" the national assembly? The repercussion of their non-inclusion in the programme is captured in the expression: "Militants threatened to return to the creeks to resume hostilities against oil multinationals" thus threatening the fragile peace which the federal was about building at the time.

Niger Delta: FG to Spend N35.8 Billion on Ex-Militants: A total of N35.830 billion has been earmarked for the "reintegration" of Niger-Delta ex-militants enrolled in the Presidential Amnesty 
Programme. This was disclosed by the Special Adviser to President Goodluck Jonathan on Amnesty Programme, $\mathrm{Mr}$ Kingsley Kuku to the House of Representatives Committee on Niger Delta, chaired by Warman Ogoriba (PDP, Bayelsa). DATA B8

Explaining the allocation, Kuku said of N38.909 billion had been appropriated for demobilised ex-agitators, while the sum of N546 million was provided for the reinsertion/transition safety allowance for 3, 642 transformed ex-agitators and their leaders enlisted in the third phase of the Amnesty Programme, in compliance with the United Nations Disarmament, Demobilisation and Reintegration (DDR) Charter Code. DATA B9

Extracts A8 and A9 above show the readiness of the federal government to take off the amnesty programme by earmarking a specific amount of money to execute the project: Niger Delta: FG to Spend N35.8 Billion on ex-militants reintegration. The use of the lexical item "reintegration" portrays the ex-militants as people who were disconnected from a normal lifestyle for a very long time thus necessitating a large chunk of money such as N35.8 billion naira to ensure their "reintegration". The requirement of such an amount demonstrates the level of negligence that the Niger Delta region had been subjected to thereby leading to a loss of human and material resources. Apart from the word "reintegration" the extract also made use of other lexical items such as "Reinsertion/transition" "transformed ex-agitators" to denote the willingness to work in accordance with the acceptable codes based on the international practices of Disarmament, Demobilisation and Reintegration. The term reinsertion is not a word that can be found in the dictionary but to insert according to the BBC dictionary is to: "put an object into something" but for the reporter to extend the use of inserting to humans' incorporation is a case of style. Transformed ex-agitators is another expression that calls our attention to the issue of linguistic labelling which predominates the media reportage in covering insurgency in Nigerian.

\section{THE BOKO HARAM CASE STUDIES}

Unlike the Niger Delta debacle, most people believe that the killings and destruction of the Boko Haram insurgency in the north are similar to the Niger Delta militants in the south-south "Boko Haram has common similarity with the Niger Delta militants which has also destroyed the economy of this country on a large scale and many innocent lives were lost as the Emir of Zuru and chairman of Zuru Emirate Council Muhammadu Sani Sami observes:

“The late President Umaru Musa Yar'adua decided to grant them amnesty in spite of opposition from various quarters, the moment the amnesty became a reality, the Niger Delta militants emerged and showed interest to give up their fight for an amicable settlement," (Weekly Trust Saturday $6^{\text {th }}$ April 2013). DATA C1 
$\mathrm{He}$, therefore, urged the Federal Government to look into the issue to temper justice with mercy and not to mind the few who, according to him is making money out of the crisis. However, other sympathisers tend to agree that the two militia groups have destructive tendencies and therefore, should be treated equally:

Interestingly, many of those that have condemned the Odi massacre, including President Goodluck Jonathan - remember the embarrassing altercation last year between him and former president, General Olusegun Obasanjo, over the massacre?- and supported the granting of amnesty for the Delta region's militants are the same people that have since been advocating the use of the same force, indeed an even more brutal one than that used in Odi, as the only solution to Boko Haram (Daily Trust, October $\left.9^{\text {th }}, 2013\right)$. DATA C2

The Punch newspaper of March $14^{\text {th }} 2012$ was said to have described the Boko Haram as "outrageous" and "gravely precarious" and was said to have praised amnesty for the Niger Delta militants as a "panacea for peace in the hitherto restive oil-rich Niger Delta." In its editorial of February 8, 2011, said "Soldiers and other security agents, even if they are professionally neutral, cannot bring lasting peace to Plateau State. The people of the state must begin an honest search for peace." The difference between the two insurgent groups, however, is the claim that Boko Haram is faceless and its goals and demands are irrational. In an editorial from the Daily Trust, one of the media outfits from which data are generated for analysis in this study, the quote below sets out to ask certain fundamental questions about the future of the Boko Haram without dialogue which could lead to the granting of amnesty to the sect group:

At least twice the Boko Haram was persuaded to dialogue with the government and lay down its arms. Each time someone, obviously an insider, leaked the move to a select media before negotiations had even begun in an apparent attempt to scuttle the talks. Worse, the authorities arrested those the sect sent to begin the talks. Whatever anyone may think is the difference between Boko Haram and MEND as a beneficiary of amnesty, the fact is that the militants did not come out from the creeks where they operated until it was clear that late president, Umaru Yar'adua, was sincere in his commitment to bring an end to the problems of Niger Delta. (Daily Trust, October $9^{\text {th }}, 2012$ ). DATA C3

From the foregoing, this segment focuses on the analysis of media reportage on the quest for amnesty for the Boko Haram sect which has been described as faceless and unapproachable by both the highly and lowly placed in the society.

AMNESTY TO GHOSTS: I hope the Americans are watching Naija's tackling of the Boko Haram insurgency with keen interest. Aso Rock has a lot to teach them on how to end an insurgency without going bankrupt. Let's hope that spoilt Americans (like their Egyptian counterparts) won't run out of patience before the dramatists have broken their legs. DATA C4 
By Aso Rock Terrorism Manual, the first blow to an insurgency is to deny its existence. If that fails to nail it, describe it as a gangup by sectional political losers to frustrate your government. When that tale becomes stale, you move to the next step, which is to claim that the insurgents are actually members of your cabinet. DATA C5.

Extracts A1 and A2 above take the form of a commentary by first asking rhetorically whether the Nigerian government is watching the unabated destructive tendencies of the rampaging Boko Haram sect as it perpetuates hostilities on the helpless populace? Our attention is however focused on certain lexical items which tend to demonise the Nigerian state as an unserious, nonchalant, and incompetent seat of power. The text compares Boko Haram insurgents to dramatis personae and intertextually relates the same to "Nollywood actors" with the intention to make the whole exercise look like a movie. Boko Haram is also compared with the militants in Egypt whose aim in insurgency is on the need for a change in governance and not the institutionalization of a religious system of government. As if mocking the sitting government or trying to expose the lacklustre attitude of the same government, the reporter makes utterances that lampoon the leadership: "deny its existence" "describe it a gang-up by sectional political losers to frustrate your government" "When that tale becomes stale....claim that the insurgents are actually members of your cabinet". All these utterances portray the government as that which is laying blames on some clandestine forces to remain unblemished. Extract A12 below gives a graphic repercussion of the continued negligence:

How did 42 school children get slaughtered while writing their university entrance examinations? Such matters are beyond the comprehension of President Jones who packed a few presidential jets and flew to Beijing for prayers. Naija ghosts do not bow to Chinese witchcraft or exorcism. Mr President, people are still dying and there is no predicting where next your ghosts would strike. DATA C6

The text accuses the then president of being lackadaisical about the issue of Boko Haram terrorism which is ravaging the nation. The word "slaughtered", paints a picture of gloom and inhumanity on the part of the insurgents. The use of the word "Naija ghosts" refers to the members of the sects who had been described as "faceless", thus prompting the use of that particular word in describing them. The then-president was also said to have gone to China for prayers as if to exorcise the spirit of militancy and the reporter was quick to say that the spirit of militancy is resistant to foreign prayers and that the delay in tackling the issue could portend danger to the uncertainty of the next "ghosts" target. The reporter concludes by saying:

In fact, two weeks ago, ghost insurgents found their way to the sleepy town of Konduga where they slaughtered 44 human beings. Your amnesty committee is still on the road, somehow immune from attack. What Naija citizens trying to survive a messed up nation and a mismanaged economy want is to continue to live like zombies, to pray in their mosques and churches without fear and to live till the next day. They can't 
stop the grand looting or prevent the amnesty committee members from cashing their fat allowances. Is there a roadmap to subsistence? DATA C7

The above extract is an expose' on the persistent refusal to grant amnesty to the faceless" group which most that are sympathetic to are advocating. By describing them as "ghost insurgents" the reporter is making a mockery of the position of the federal government because can hardly "found their way" as expressed in that first line of the extract where they "slaughtered 44 human beings" as if they are animals meant for sacrifices. The reporter further made mention of the amnesty programme as a panacea for the "arrest" of the ugly situation but in a mocking form and believes that the "a messed up nation and a mismanaged economy" is still better for the citizens than a battered and unsecured place unfit for human habitation. There is also an accusation on the part of government officials who are supposed to implement the amnesty programme as people who would rather take refuge in "cashing their fat allowances" thus placing a question mark on the sincerity or otherwise of the federal government. This is also a form of mockery on the amnesty programme being implemented in the Niger Delta region where the officials are seen to enrich themselves in the name of alleviating the sufferings of the Niger Delta ex-militants even to the knowledge of the federal which is said to have turned a deaf ear to the people's yearnings and aspirations. Despite the above position on the issue of amnesty for Boko Haram, the system seems to be polarised along religious lines where the federal government is accused of engineering the amnesty committee to only visit Christians as opposed to both Christians and Muslims as quoted in the extract below:

Insurgency: Group Accuses F.G of Selective Attention: A Muslims' organization Munazzamatu Fityanil Islam has expressed concern over the inability of the Presidential Committee on Dialogue and Amnesty to visit the affected Muslims and mosques during its official tour to the affected people and places by insurgency. DATA C8

A statement signed by the organization's National Secretary, Sheikh Tijjani Bala Kalarawi in Kano yesterday said Munazzama noted through various media reports that the committee had only visited victims of the Sabon-Gari bomb blast and the affected Churches in Kano, Madalla, Abuja and Kaduna state. It said: "but the committee did not visit Muslim victims in Kano, Borno, Yobe, Adamawa, Kaduna, Bauchi and Gombe states among other places affected by the insurgency. And there was also no media report indicating the committee's visit to any mosque destroyed in those areas." The statement further noted that even in Kano state, where the committee visited about 10 victims of the Sabon Gari bomb blast, it neither paid a similar visit to the families of over 200 Muslims that were killed during the first bombing nor to the Emir of Kano, Alhaji Ado Bayero, who was also attacked by unknown gunmen. DATA C9 
Nigeria being a multi-religious state can hardly survive the allegation of religious extremism as and religious "patronism" as observed above. The grievous allegation is found in these expressions: "expressed concern over the inability of the Presidential Committee on Dialogue and Amnesty to visit the affected Muslims and mosques" "noted through various media reports that the committee had only visited victims of the Sabon-Gari bomb blast and the affected Churches" "but the committee did not visit Muslim victims" "And there was also no media report indicating the committee's visit to any mosque destroyed in those areas." The statement further noted that even in Kano state, where the committee visited about 10 victims of Sabon Gari bomb blast, it neither paid a similar visit to the families of over 200 Muslims that were killed during the first bombing". All these are chilling allegations that cannot be overlooked because they could trigger further religious skirmishes and shatter the peace that hardly exists in the nation. And to say those insinuations were made through the media as alleged above, then portend danger because sectionalism in media reportage could breed hatred and acrimony among the citizens of any nation if not properly checked. For the media to report that the committee visited ten Christian victims but failed to visit two hundred Muslim victims in our view is a ploy to foment trouble along religious lines. A report on June 26, 2011, explains why the Boko Haram sect is adamant to embrace the amnesty programme even when the federal government is foot-dragging in that area:

Rejecting amnesty, making demands, What we want, by Boko Haram: The group, two months ago, in a threepage statement purportedly written in Hausa and distributed to newsmen in Maiduguri, vowed no end to the persistent attacks, explaining that the ward and village heads, politicians, police and the army, had fell victims of its serial killings and that they have their list of targets which they will execute chronologically, "because they erred by associating themselves with the government in its effort to arrest Muslim brothers and sabotage Islam.”DATA C10

The headline spells out in clear terms what the sect wants. Their stance is simple and clear: a clear attack on those who attack their style of governance: "because they erred by associating themselves with the government in its effort to arrest Muslim brothers and sabotage Islam." This shows that the Islamic sect is not willing to associate itself with the secular Nigerian state but prefers to live in a sharia state and anybody who associates with the laws of Nigeria is an enemy of Boko Haram. The question then is: are those who advocate amnesty for the sect members aware of this position? And if they are will they be able to change their ideological stance?

Governor Kashim Shettima had after winning the April election promised to grant amnesty to the sect members and solicit for the full cooperation and understating of the three opposition parties, traditional and religious leaders. Rightly, he had noted that without peace and security of life and property, no meaningful development could take place in the state. DATA C11 
The then Bornu state governor was said to have promised amnesty to those involved in insurgency in the north-eastern part of the country especially those from his state. But their refusal to honour the same is a case for the advocates of amnesty for the sect to trash out in a court of public opinion. But the decision of the then governor to add the opposition party members, traditional and religious rulers to the list of those to be pacified is a clear indication that the much-touted amnesty for the Boko Haram sect is a political move to pacify the politically aggrieved as well as those who feel disenchanted with the political situation in the country.

The sect members surprisingly refused the offer. Recently, they transformed into Jama'atu-Ahliss-SunnahLidda'awatiWal Jihad and resolved to target security operatives and some civilians for the ongoing serial killings in Borno State following their "active support and protection" for the Nigerian system of government which they said contradicted Islamic principles. DATA C12

Extract A18 is a contradiction to the proposed amnesty by the then governor of Bornu state by the sect members who insist that their ideological stance runs contrary to the modus operandi of the Nigerian state. The sect is interested in running an Islamic sharia-like government that would be guided by the stipulations in the Quran and not by any constitution that they believe is deceitful and capable of rubbishing humanity with certain inalienable rights and obligations. The resolve to "target security operatives and some civilians for the ongoing serial killings" is an indication to challenge the legitimacy of governance and any extant laws that regulate the activities of the state as opposed to the belief of the Boko Haram.

\section{MILITANCY, VANDALISM AND BUNKERING:}

\section{The Niger Delta}

The terms militancy, vandalism and bunkering are used within this context as restrictive to the Niger Delta region which has been reddened with conflict as an offshoot of the Nigerian state crisis---a product of structural deficiencies inherent in the country and systemic anomalies within its society. The three terms overlap in their meaning relations, thus being grouped together within the same schematic arrangement. The following extracts help to bring out the hidden meaning in the texts in relation to their usages regarding the concepts under focus:

FG LOST 4TRN TO MILITANTS: During the heat of the Niger Delta militancy, the Federal Government lost as much as N4 trillion, former minister of Niger Delta Sam Odey has said: He said this was due to the dwindled daily oil production which went down to $700 \mathrm{bpd}$ compared with $2.5 \mathrm{~m}$ bpd being produced now. The former minister spoke during the National Orientation Agency (NOA) stakeholders' meeting on President Goodluck Jonathan's mid-term performance from May 2011 to May 2013. He expressed happiness that the controversial East/West road started in his time has now reached 64 per cent completion. DATA D1. 
NAVY HANDS OVER SIX SUSPECTED OIL THIEVES TO EFCC: Six suspected oil thieves and a vessel, MV SOA from the Nigerian Navy, Naval Base, Warri, Delta State for further investigation and possible prosecution: "According to Lieutenant Commander Francis Okoloagu, the navy ship NNS COBRA, while on patrol July 28, 2013, arrested the suspects on board MT ALLI-RIZA BEY and MV SOA vessels transferring petroleum product suspected to be Automotive Gas Oil to smaller boats offshore Escravos." Wilson Uwujaren spokesman of the EFCC said in a statement. DATA D2

\section{NIGERIA LOOSING 35 PERCENT POWER GENERATION CAPACITY TO VANDALISM: Nigeria is losing over $35 \%$ of her power generation capacity to the activities of vandals, the Minister of Power, Prof. Chinedu Nebo has said. The Minister made this revelation while speaking at the opening ceremony of a two-day Stakeholders Forum on the protection of critical national assets and infrastructure at the International Conference Centre, Abuja on Monday. DATA D3}

The three news extracts above share some striking similarities but is cut in the web of linguistic labelling by using three different labels to describe the perpetrators of violence in the Niger Delta region. In the first extract, there is the consistent use of the noun "militancy" and the adjective "militants". While the headline reads "FG LOST 4TRN TO MILITANTS" the news overline goes ahead to sustain the linguistic usage by quoting the then minister of the Niger Delta as saying "During the heat of the Niger Delta militancy, the Federal Government lost as much as N4 trillion". The then minister was said to have blamed the "dwindling" oil "production" rate on the activities of the "militants" and called for a change of attitude. In the second news extract, there is another use of linguistic particle which tends to portray the Niger Delta boys as common criminals as the newspaper states in its headline: "Navy Hands over Six Suspected Oil Thieves to Efcc". The reportage here is on outright criminality-a case punishable under the nation's criminal laws and penal codes, hence the need to hand them over to the country's anti-corruption agency for appropriate prosecution. The news overline goes on to state that: "Six suspected oil thieves and a vessel, MV SOA from the Nigerian Navy, Naval Base, Warri, Delta State for further investigation and possible prosecution". The role of the Economic and Financial Crimes Commissions in Nigeria is solely to see to resolving issues that bother on corrupt practices and not to prosecute criminalities or militant but because of the involvement of the Naval Vessel in the crime, the EFCC came into the picture to give criminal prosecution to the crime of militancy. It is an irony that government vessels are caught "transferring petroleum product suspected to be Automotive Gas Oil to smaller boats offshore Escravos" because these are supposed to be the protectors of the nation's territorial waters but turned "bandits". 
The link between the three extracts continues as the then minister clearly spells out the counterproductive effects of oil bunkering and pipeline vandalism. The position of the then minister of power is premised on the fact that the drop in the production capacity of the power ministry leading to inadequate supply of light is a result of the activities of vandals. The context of the location where the utterances were made is very important: "The Minister made this revelation while speaking at the opening ceremony of a two-day Stakeholders Forum on the protection of critical national assets and infrastructure". The implication of this is that the nation's "critical infrastructure" is at stake and need a serious overhaul if the nation is to increase the output of oil production as well as protect the facilities within the Niger Delta region. Extracts B22 below is a reaction to the preceding news item on the repercussions of vandalism and bunkering as a legal dimension has been introduced to justify the criminality attached to the conducts of the militants.

\section{OIL THIEVES FACE 21 YEARS IN JAIL: The Federal Government has raised the alarm that Nigeria loses N7billion to oil theft on a daily basis. The National Economic Council (NEC), which disclosed this at its yesterday's meeting chaired by Vice President Mohammed Namadi Sambo, consequently resolved that anyone found guilty of crude oil theft be sentenced to 21- year imprisonment without the option of a fine. DATA D4}

In a federal executive council (FEC) presided over by the then president, Goodluck Jonathan the decision was taken as a direct legal assault on any conduct considered inimical to the progress of the nation through "vandalism" of oil pipelines. Our interest in the story is the metaphoric use of the word "thieves" to label those who vandalise oil pipelines. The media switches from "bunkerers" to "militants" "criminals" "thieves" to "bandits" etc. and this kind of labelling is judgemental as Chouliaraki and Fairclough assert:

Some representations reflect reality more loyally than others according to some external measure. Such an interpretation is out of line with their definition of truth as a product of a democratic discussion but fits well with their distinction between more or less ideological discourses. According to this interpretation, Chouliaraki and Fairclough circumscribe relativism, viewing all representations as socially constructed (a relativist position), but seeing some as more loyal to reality than others (a non-relativist position). From a social constructionist perspective, the question arises here as to who should pass judgement as to which representations are better than others. If the choice of one representation over others is not the product of struggle in a discursive field, there must be someone - such as the researcher - who decides by virtue of their privileged insight (2002:198)

There is no consistency in linguistic labels when it comes to the issue of militancy reportage in Nigeria and such labels are judgemental. The use of the word "thieves" is closely followed by the word "theft" in the sentence: anyone found guilty of crude oil theft be sentenced to 21-year imprisonment without option of fine with the pronouncement making "bunkering" a capital offence which does not carry any form of appeal or option of a fine. As if daring the presidential 
fiat on the issues of vandalism, security operatives were said to have arrested pipelines "vandals" as stated below:

POLICE ARREST 10 PIPELINE VANDALS: The Nigeria Police have arrested 10 oil pipeline vandals and recovered 800 units of 50 litres jerry cans filled with stolen oil in Ogun state. Inspector-General of Police Mohammed Abubakar said this yesterday saying the force was closing in on criminals who have been vandalising pipelines belonging to the Nigerian National Petroleum Corporation (NNPC) across the country. DATA D5

POLICE CAN'T PROSECUTE PIPELINE VANDALSCOURT: The authority of the police to prosecute crimes has again suffered a major blow as a Federal High Court sitting at Lokoja; Kogi State held that the police's power to prosecute pipelines vandals has been transferred to the Nigeria Security and Civil Defence Corps (NSCDC). "This means that even if it is the Nigeria Police that apprehended any person suspected to have committed such offence, it is the duty of the police to hand over such suspect to the NSCDC for prosecution." The case that resulted in the judgment was a one-count charged filed by the police against one Abuh Daniel who was said to have loaded one big storex tank with crude oil without a licence.

DATA D6

The headline on extract B23 runs contrary to the content of the news in terms of the critical appraisal of the lexical items found therein; "ARREST 10 PIPELINE VANDALS" does not collocate with "stolen oil" because vandals destroy but on a closer look at the content we see the same report saying "the force was closing in on criminals who have been vandalising pipelines". But extract B24 tends to nullify the federal government's stance on prosecuting the so-called "criminals" "bunkerers" "thieves" "vandals" etc. as we are told that: "POLICE CAN'T PROSECUTE PIPELINE VANDALS-COURT" with this kind of pronouncement from the court, it calls to question who these "criminals" are if they are not highly-placed individuals in the society. On a closer look at the above headline, it looks contradictory and confusing. The content of the news is quite different from the main news. The headline is "sensational" misleading" and intended to call attraction to potential buyers who would want to know why "the police cannot prosecute vandals as said by the courts" only for such a buyer to discover that the prosecutorial powers as reported are not in the Nigerian police but on the National Civil Defence Corps as stated "that the police's power to prosecute pipelines vandals has been transferred to the Nigeria Security and Civil Defence Corps (NSCDC). This means that even if it is the Nigeria Police that apprehended any person suspected to have committed such offence, it is the duty of the police to hand over such suspect to the NSCDC for prosecution. This position clearly substantiates van Dijk's belief that: 
Headlines are particularly important because, both in production and in the reception of news reports, they subjectively define the most prominent or most relevant information of the news item. They express-sometimes in a biased way-the top of the underlying semantic macrostructure, and at the same time define the situation in the press. Since headlines and leads are often the only information read or memorized, they play an important role in further information processing and the possible effects of news (1988:189).

This, therefore, follows that headlines are sometimes purposely structured to mislead the reading of the news by attracting potential buyers to the newspaper only for the buyer to discover that the content of that particular news item is quite different from the headlines flashed on the front page of the newspaper. The extract B25 below is a typical example of overgeneralization in terms of language usage. The headline poses a threat by stating the obvious:

Niger Delta ex-militants threaten to halt oil production: NIGER Delta ex-militants, also known as ex-agitators, under the Phase Three Amnesty, have threatened to halt oil production in the region. DATA D7.

As a way of justifying their reportage, the extract above portrays the paper as saying that the Niger Delta militants "have the capacity" to "halt" oil production in the entire country. But the switch from "ex-militants" to "ex-agitators" is worrisome because the essence is to give sympathy to the perpetrators of violence in the region. If the journalist says they are "exmilitants" and they are also known as "ex-agitators" then what is the position of the media house because those two labels are direct opposites of what they actually are supposed to be in terms of linguistic usages. The process of "halting" production in the entire country does not involve a particular militant group but where others had embraced the amnesty programme, it then becomes difficult for any group to achieve such a goal.

Ex-militant Raises the Alarm over Arms Build-up in Niger Delta: Niger delta militants: Seeks UN, US intervention: An exmilitant in the Niger Delta region, Mr Kennedy West, has warned of a heavy arms build-up in the region, stressing that the area might witness another orgy of violence if immediate steps were not taken. He called on the federal government to urgently embark on another round of disarmament programmes in the region to avoid a return to the pre-amnesty era. DATA D8

"We want to tell you that the arms in the Niger Delta region are more than what people think. The arms in this region now are two times bigger than what the militants from various camps submitted in 2009 , under the amnesty programme. The arms here are two times heavier than what we had here in 2009. DATA D9 
Extracts B26 and B27 tend to prove extract B5 right that the militants have the capacity to launch an attack that could "halt" oil production in the country if their activities are not checkmated by the appropriate authorities. A "repentant militant" himself raises the alarm as reported in that headline that it will only take the intervention of the United Nations and the United States to rescue the situation as the arms build-up in the region is "overwhelming". According to the ex-militant" the area might witness another orgy of violence if immediate steps were not taken" this is also a wakeup call for those who have gone to sleep believing that because the amnesty programme has been implemented in the Niger Delta region and that because "the boys" "have been settled" the area is now calm for business as usual, and as the reporter did say in that report that the arms in the region were "two times" bigger than the ones that were recovered during the disarmament programme, it therefore implies that "the reporter's personal emotion is brought into the reportage to further heighten the tension in the region by calling the attention of all stakeholders into that region and making it a centre of attraction. The level of militancy in the region as exhibited by the militants and as reported in the media can be seen as a situation that can go beyond the Niger Delta region. This is exactly the position of the next extracts as we observe that the Atlas Cove jetty in Lagos was under heavy attack by the militants who travelled all the way from their region to the South Western part of the country to unleash terror.

In a brazen attack that lasted over three hours, conducted outside the boundaries of the Niger Delta, suspected militants yesterday, blew up the receptor pipelines inside the Atlas Cove jetty, effectively crippling the capacity of the facility to receive petroleum products. Admiral Ishaya Ibrahim, the Chief of Naval Staff disclosed that the attack left three naval personnel, including an officer dead, while an eyewitness added that four labourers also lost their lives. DATA D10

They (attackers) really took their time. It was as if they had inside information of the operations of the jetty. They also stormed the armoury and carted away available arms and ammunition. After scaring off the security personnel, they proceeded to place dynamites on a critical angle of the pipelines linking the receptor jetty and blew it up, the eyewitness disclosed. When Vanguard visited the area at about $1.30 \mathrm{pm}$ yesterday, the charred remains of the officers including the officer, a Navy Commander, who was said to have assumed duty barely three weeks ago at the Atlas Cove, were spotted on the ground. DATA D11

MEND claims responsibility: The Movement for the Emancipation of the Niger Delta (MEND) claimed responsibility for the attack in a statement sent by email to the media, saying its fighters launched an attack on the Atlas Cove Jetty in Lagos state overnight, the first in the area since the group began its latest campaign in May. Destroyed Receptor pipeline for refined 
petroleum products at the Atlas Cove Jetty which is responsible for $35 \%$ of the nation's daily consumption of petroleum products by MEND. The depot and loading tankers moored at the facility are currently on MEND claimed. DATA D12

The above is a clear indication that militant activities can take place anywhere not minding the religious affiliations of the perpetrators of the acts. It is clearly spelt out in the extract above, that the militants "took" their time in a "brazen" attack that lasted several hours. Meaning, they were not afraid of any form of obstruction from any angle because they felt the security operatives attached to guard those facilities could not pose any threat to them. The report did say that "they blew up the receptor pipelines inside the Atlas Cove jetty, effectively crippling the capacity of the facility to receive petroleum products". Since this is the receiving end of petroleum products from the main source which is the Niger Delta region, they (the militants) had to "blow" it up to stop the flow of petroleum products thus giving credence to the use of the word "halt" in our previous discourse. Our major interest is in the aspect of the report that says "the attack left three naval personnel, including an officer dead, while an eyewitness added that four labourers also lost their lives". From the foregoing, the spokesman for the Naval base reported the death of his "men and even emphasized the death of the "officer" but the death of "three labourers" was reported by an "eyewitness" who had no business with the modus operandi of the jetty. In a swift reaction to the bombing that took place, the militant group in the Niger Delta region, the Movement for the Emancipation of the Niger Delta, (MEND) was said to have "claimed" responsibility for the attack and even threatened to launch more attacks if their condition was not reversed. The attack paralysed the flow of the oil products which the report claims account for thirty-five per cent of the nation's consumption rate.

\section{CONCLUSION}

Having explored the linguistic contents of news reports in the selected media outfits, we realized that: newspaper reports expose the ideologies that shape news especially in crises situations. Through this process, news reports assist members of the public to re-evaluate their perception of the insurgents, their activities and their ways of thinking based on media depictions. The study establishes the fact that the media conceptualizes insurgency in Nigeria in ideological terms because ideological depictions are strong source domains given that they provide a clear path with start and end points in any form of discourse. This study thus unveils the fact that: language use in the media in relation to crises reportage is judgmental and that it is capable of causing disaffection through linguistic labels

\section{REFERENCES}

Fowler, R. (1981). Literature as Social Discourse.London: Batsford.

Fowler, R. (1991). Language in the news. Discourse and ideology in the British press. London: Routledge.

Fowler, R., Kress, G., Hodge, B., \& Trew, T. (1979). Language and control. London: Routledge \& Kegan Paul.

Fowler, R., \& Hodge, B., Kress, G., \& Trew, T. (1979). Language and control. London: Routledge \& Kegan Paul. 
Ghevolor, A. J. (2013). The impact of women's conversational style on ideological and sociocultural stability in Toni Morrison's Sula" in Currents in African Literature and the English Language (CALEL). Volume VI.

Ghevolor, A. J. \& Essien-Eyo, A. (2018). "Transculturalism and feminist ideology in Ama Ata Aidoo's The dilemma of a ghost" in Currents in African Literature and the English Language. (CALEL). Volume VIII.

Innocent, Chiluwa. Ethnic Militia, the Press and the Nigerian Government: Examining the Discourse of 'Amnesty' and Identity' from ichiluwa@gmail.com Freiburg, Germany. Retrieved on the 18:06:2012

Kress, G., \& Van Leeuwen, T. (1980). Reading Images. Victoria: Deakin Uni. Press.

Martin Rojo, L. (1994). Jargon of Delinquents and the Study of Conversational Dynamics. Journal of Pragmatics, 21(3), 243-289.

Martin Rojo. Division and rejection: from the personification of the Gulf conflict to the demonization of Saddam Hussein in Discourse \& Society, 6(1), 49-79.

Martin Rojo \& Van Dijk, T. A. "There was a problem, and it was solved!" Legitimating the Expulsion of 'Illegal' Immigrants in Spanish Parliamentary Discourse. Discourse \& Society 8(4), 523-567.

Matthew Ebim Abua (2021) Insurgency and Militancy in Nigeria. Mauritius: Scholars' Press

Matthew Ebim Abua \& Tanyi, J.N. "A Discourse Study of the Nigerian Army and Boko Haram

Counter-Propaganda Rhetoric" in NDUNGODE, Calabar Journal of the Humanities, 17(1) (Pp101-114). January 2021.

Matthew Ebim Abua "The Semiotization of Boko Haram Insurgency: A Critical Linguistic

Perspective" In NDUNGODE, Calabar Journal of the Humanities. 16 (1), 33-49

Matthew Ebim Abua “ A Multimodal Analysis of Niger Delta Discourses" in Language and Literary Studies in Society, A Festschrift for Professor Eno Grace Nta @ 65. Lagos: University of Lagos Publishing Press, 2021. 189-209.

Matthew Ebim Abua "Terrorists or tags"? Contested identities in media portrayal of militants in Nigeria" in Mgbakoigba, Journal of African Studies. Vol.6 No.2. February 2017

Matthew Ebim Abua (2017). "A Critical Discourse Analysis of Print Media Depictions of Insurgent Activities in Nigeria" An Unpublished PhD Thesis in the Department of English University of Lagos, Submitted to the School of Postgraduate Studies University of Lagos, Akoka Lagos.

Otive, Igbuzor. '(2011). Peace and security education: A critical factor for sustainable Peace and national development' in International Journal of Peace and Development Studies Vol. '2(1), pp. 1-7, January 2011http://www.academicjournals.org/IJPDS Retrieved on the 22:08:2013

Rotimi, Taiwo. (2007). 'Language, Ideology and Power Relations in Nigerian Newspaper Headlines' in Rotimi, Taiwo, Akin, Odubunmi and A. Adetunji (eds) Perspectives on Media Discourse. Muenchen Lincolm.

Rotimi Taiwo, O. and Akin-Aina, T. (1991). Environmental Implications of Oil-Production and Policy Framework in Nigeria, in Tomori, S. ed; Oil and Gas Sector in the Nigerian Economy, Lagos: Faculty of Social Sciences, University of Lagos, Nigeria.

Reah, D. (1998). The Language of Newspapers. London: Routledge.

Wodak, R., de Cillia, R., Reisigl, M., \& Liebhart, K. (1990). The discursive construction of National Identity. Edinburgh: Edinburgh University Press.

Wodak, R. (1986a). Language Behavior in Therapy Groups. Los Angeles: UCP. 
International Journal of Literature, Language and Linguistics

ISSN: 2689-9450

Volume 4, Issue 1, 2021 (pp. 64-88)

www.abjournals.org

Wodak, R. \& M. Schulz (1986b). The Language of Love and Guilt.Amsterdam: Benjamins.

Wodak, R. \& M. Meyer (2001).Methods of Critical Discourse Analysis. London: Sage.

Wodak, R. (2004). "Critical discourse analysis". In C. Seale, G. Gobo, J. F. Gubrium, \& D. Silverman, Qualitative Research Practice (pp. 197-213). London: Sage.

Wodak, R. \& M. Schulz (1986b). The Language of Love and Guilt.Amsterdam: Benjamins. 